\title{
A Black, Great Horned Owl
}

\author{
S. A. MANN, Skull Creek, Sask.
}

About the middle of October while travelling north of Gull Lake with some friends we saw an almost black Great Horned Owl. It had been injured and could not fly so we were able to get quite close to it. The only part of it which wasn't black was a little piece from wings to tip of tail. This was mottled with dark gray.

I wanted to take it as a specimen for the museum but our friend would not hear of its being taken, even for that purpose. As it was about fifty miles from home, I didn't care to go back next day on a chance of finding it.

EDITOR'S NOTE: Taverner has this to say. "The Great Horned Owl is a very variable species and divides into a number of geographical races. Many attempts have been made to find them, but when tested by specimens of breeding birds, none of them is entirely satisfactory. The following races are recognized in Canada in the American Ornithologists' Union Check list. 'The typical Eastern Great Horned Owl contains much warm ochre and neither black nor white is particularly prominent. The Arctic Horned Owl is almost pure white. The Western Horned Owl is a light-coloured bird, characterized by much light ochre underplumage. It is expected in the southern parts of the Prairie Provinces. Throughout the mountains of British Columbia we have a dark form, the Pacific Horned Owl, much blacker than the Eastern Horned Owl. In northern British Columbia and adjoining parts of the Yukon is a similar black form, the Northwestern Horned Owl. It is interesting to note that these dark western forms are almost identical in coloration with the Labrador Horned Owl, though separated from it by thousands of miles, and with an almost white race between. The species is suspected of being dimorphic to some extent, and the black coloured birds are supposed to occur in all races."

\section{Disputed Territory}

Mrs. George H. Johnson, Hassan, Sask.

There is a place between our, house and granary that all the birds seem to like in the spring during the migration period. We have counted as many as ten different species feeding here at one time. Sometimes there will be over a hundred birds feeding here. We enjoy watching them from the window.

Last spring, after many had come and gone, a pair of Robins and a pair of Killdeer Plovers decided that this was their o w n private feeding ground and proceeded to chase all other comers away. Then they started to battle it out between themselves for sole possession. Finally they gave up the hopeless struggle, the Robin staying at the north side and the Killdeer staying at the south. There they remained until late in summer. No intruders were allowed there - my, how they did chase them! After their young were hatched they disappeared.

In our yard we also have had a pair of Bluebirds that have returned for the past three years. Each time they nested in an old binder twine box. They are so pretty to watch!

\section{An Emissary}

\section{Arthur Ward, Swift Current}

It was 3 p.m. - the day of October 2nd, last year. Walking within the fringe of trees, I noticed a bird flying towards me from the dugout. It lit within a dozen yards. Not discerning it clearly at first suggested to me a Flicker, but no! - of all the surprises, it was "The Blue Jay".

This was the first instance one had ever been seen here. Did it say "Hello"? Anyway we regarded each other in a friendly manner, and it flew to a branch over my head. I could not help but regard it as an emissary. In expression it seemed to say: "I just called to see how you were getting along, I've other places to go and must be on my way." It then flew just north of the bird traps and discoursed some" Blue Jay Chatter". 'Hoping it might want to investigate the traps and allow me to present it with a ring, I hastened to the arbour and brought out my bird calls. The orchestral notes, however, were of no avail. I searched the grove only to find that it had simply vanished, leaving me reminiscent regarding some Person, we once knew and have not forgotten. 